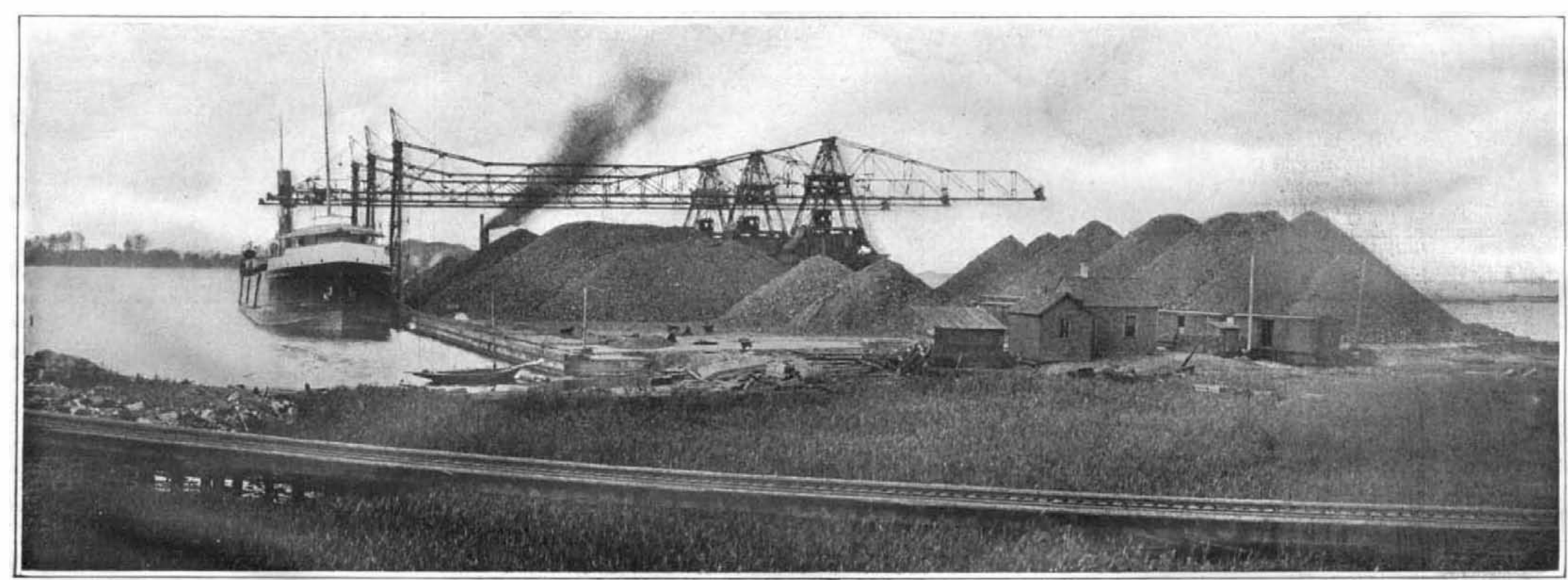

Unloading coal at a lake port.

\title{
The Use and the Waste of Our Coal Supply
}

\section{At the Present Rate Coal may be Exhausted while the Nation is Yet Young}

By Dr. Joseph A. Holmes, Director of the Bureau of Mines

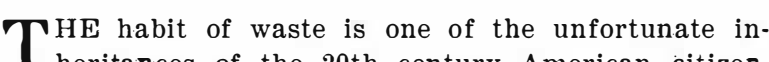
1 heritances of the 20th century American citizen. It is our most serious hinderance to the development of both individual and national efficiency. More than anything else, it stands in the way of the wise use or conservation of the resources, ample, present and future, supplies of which are essential to our individual and national welfare.

This fact is important enough to command attention when applied to products of the soil, of which we have new supplies each year; or to our forests of which each century may bring returns; or to the soils themselves to which the underlying rocks slowly yield new additions as by careless culture we permit the fertile surface to be eroded and carried off to the sea. It is still more important when applied to our mineral resources, of which we have but the one supplywhich supply has required millions of years for its accumulation, and which supply at the present increasing rate of consumption may be exhausted while the nation is yet young; and especially when applied to our fuel resdurces, of which the portions used each day are completely destroyed.
And, yet, the very abundance, and supposed abundance, of our mineral resources has developed and en couraged the habit of waste. A legislator of many years' experience in national affairs, was recently. quoted as saying in a public address: "Why, worry ourselves about a future coal supply when there is undiscovered coal enough in the Rocky Mountain re gions to warm this nation for an indefinite future." Another of our "older statesmen" has in recent public utterance-voiced the same view: "We have enough coal and to spare" he said, "for a thousand decades of our national history; therefore, we need not concern ourselves about the use, nor the waste of American fuel." And the average citizen has so long heard so much about the "exhaustless resources" of this country, that he is half way inclined to believe such statements

It is only within the past few years that the real facts of the situation have impressed themselves upon us. The end of the coal supply in certain importan centers is found to be already nearly in sight. The cold-blooded statistician studying the future in the light of the past, tells us that, if the increasing rate of consumption of the past century be continued in the future, our national coal supply may be exhausterl within less than two hundred years. The States that first feel the effect of this fuel exhaustion, in spite of their larger supplies, will be those like Pennsyl(Inia, West Virginia, Ohio, Illinois, and Iowa, located near great manufacturing and transportation centers, and upon whose supplies the largest drains are being made---both in the use and the waste of essential resources.

Be this all as it may, as to one fact and principle all thoughtful citizens must agree, namely, that while no one questions the right of each generation to use efficiently of this coal supply all it really needs, this right carries with it a sacred obligation-that no man and no generation of men shall waste that which is not needed for its actual use, and which, therefore, belongs to the nation.

Waste in Mining Coal

The fact that the loss of coal in mining operations now approximates $250,000,000$ tons per annum; or that we leave underground in such condition as to make its future recovery impracticable, half a ton for every

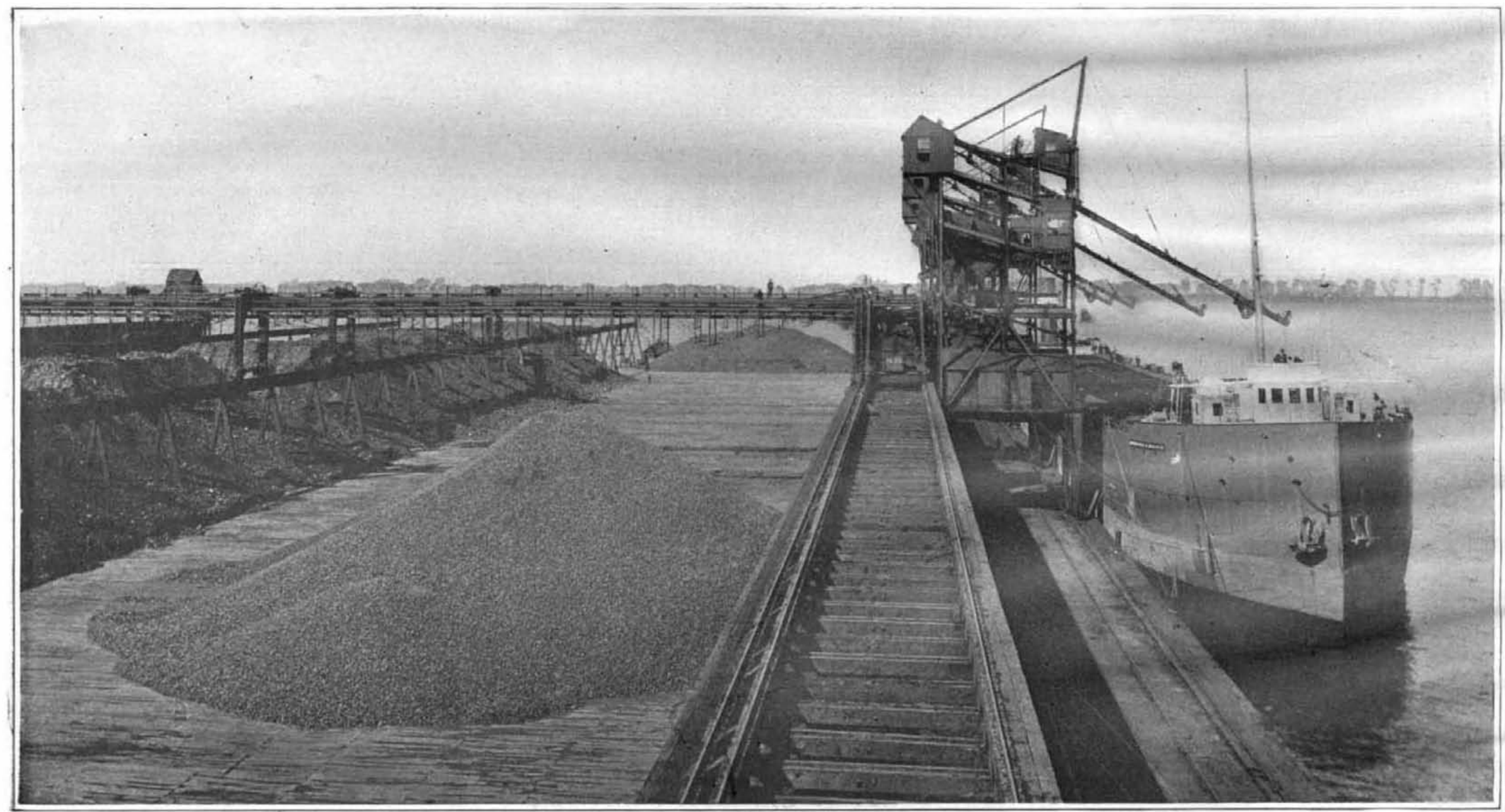

Removing coal from hold of lake steamer to a storage platform.

THE USE AND WASTE OF OUR COAL SUPPLY 
ton of coal now brought to the surface, is a fact that commands serious consideration. And what make a bad matter worse, is the fact that this coal left underground is often a menace to property by originating or harboring mine fires, and often a menace to life by developing supplies of explosive mine gase that may by falls or settling of roof be driven unexpectedly into the working parts of the mine, where open lights or other agencies may ignite it and cause a mine disaster.

In some mines from eighty to ninety per cent of the coal is brought to the surface. In many mines the recovery ranges from sixty to seventy-five per cent of the whole, while in some mines the recovery is from forty to sixty per cent. In some cases this loss con sists mainly of the pillar coal left in place to support the roof while the other coal is being removed, and which pillar coal may be later not re moved or only partially removed.

In addition to this pillar coal in many mines there is a "roof coal," o "rooster coal," or "top coal," and also a "bottom coal," which is also left underground because lower in quality or more expensive to mine.

Additional losses of coal coming from the pulverizing action of the drills and coal cutting machines (see photo), from the grinding of coal under the wheels of the mine cars (see photo); and from the sorting or screening and washing and general handling about the shaft and tipple. Much of the fine coal in the mines is not removed and remains as a menace to life if involved in dust explosions. Much of the fine coal removed from the mines accumulates in the great black piles of culm, where it may or may not burn from spontaneous fires; or it may be shipped away and marketed as slack; or in a few cases this fine coal is being briquetted and sold at prices as high as those obtained for the best lump coal.

All the above sources of waste re late to the losses in mining a single bed of coal. Still other losses come where several beds of coal occur one above the other with thin intervening beds of rock, from the prior mining of the lower bed. This often results in an irregular breaking and settling of the overlying bed or beds of coal in such a manner as to seriously inte:fere with the subsequent mining and recovery of this overlying or upper coal.

In other countries regulations re quire in such cases the prior mining of the overlying or upper beds of coal, in order to avoid this unnecessary settling and breakage of successive higher beds. But in the United Statos each company has followed the law of "present profits" and least resistance; and the "future welfare of the nation" has remained an irridescent dream

Losses in the Transportation of Coal. From the shaft and the tipple the coal falls into the forty or fifty-ton coal cars for transportation by rail (see photo), or into the barges for transportation by river (see photo). In these transport barges, as seen on the Ohio and Mississippi rivers, a single small stern-wheel steamer attached at the rear of the group of the barges, may carry to New Orleans from 40,000 to 60,000 tons of coal (photo).

If intended for ocean or lake transportation by steamer, the coct may be allowed to run from the opening in the bottom of the car (or an elevated track) directly into the hold of the steamer; or each car may be elevated separately and inverted, the coal rushing down the chute into the steamer's hold. At the other terminal port the coal whether transported by barge or steamer is lifted by great

steel grab buckets and placed on storage platforms (see photo), or ayain placed on cars for further transport (see photo). At every handling of the coal there is an increase of fine coal or slack (photo), and a small per cent of loss. But often the total actual waste in the haulage, including the several transfers,

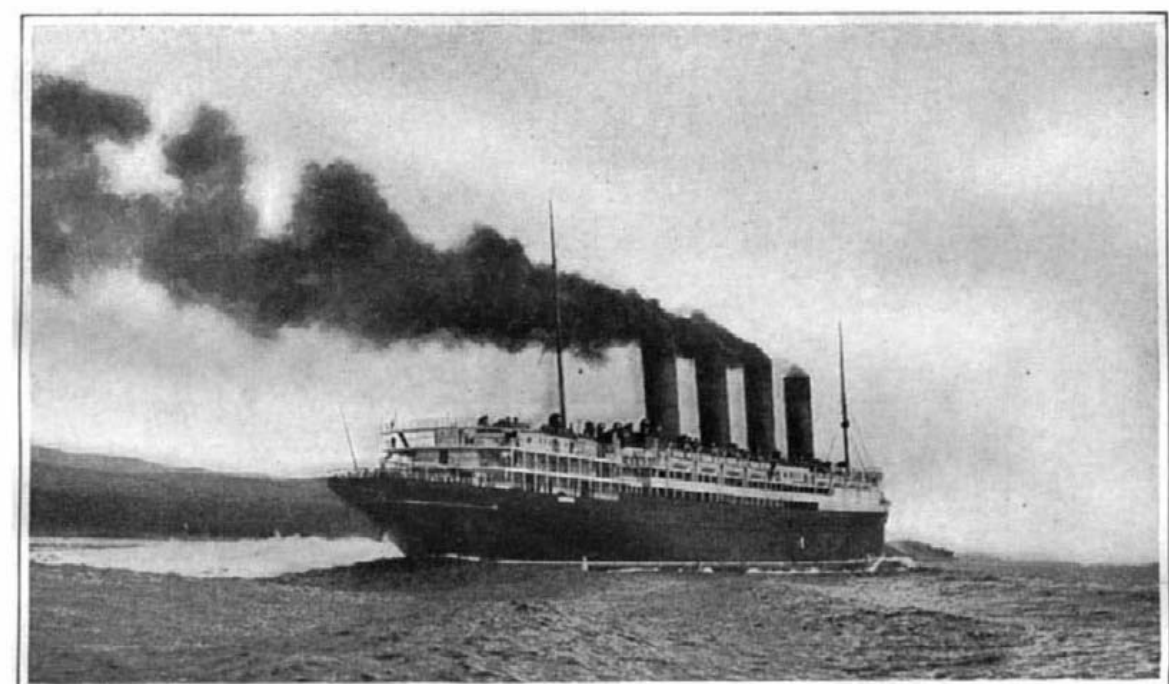

This ship consumes 1050 tons of coal each day.

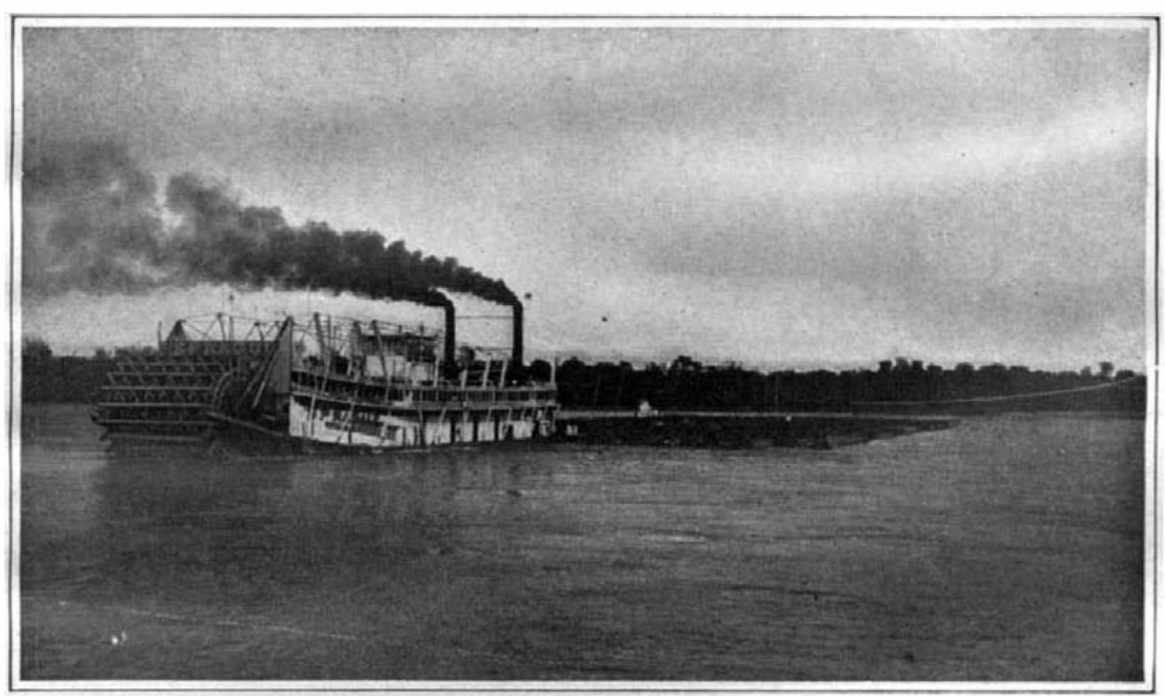

Steamer "Sprague" towing 56 coal boats, containing 1,400,000 bushels of coal.

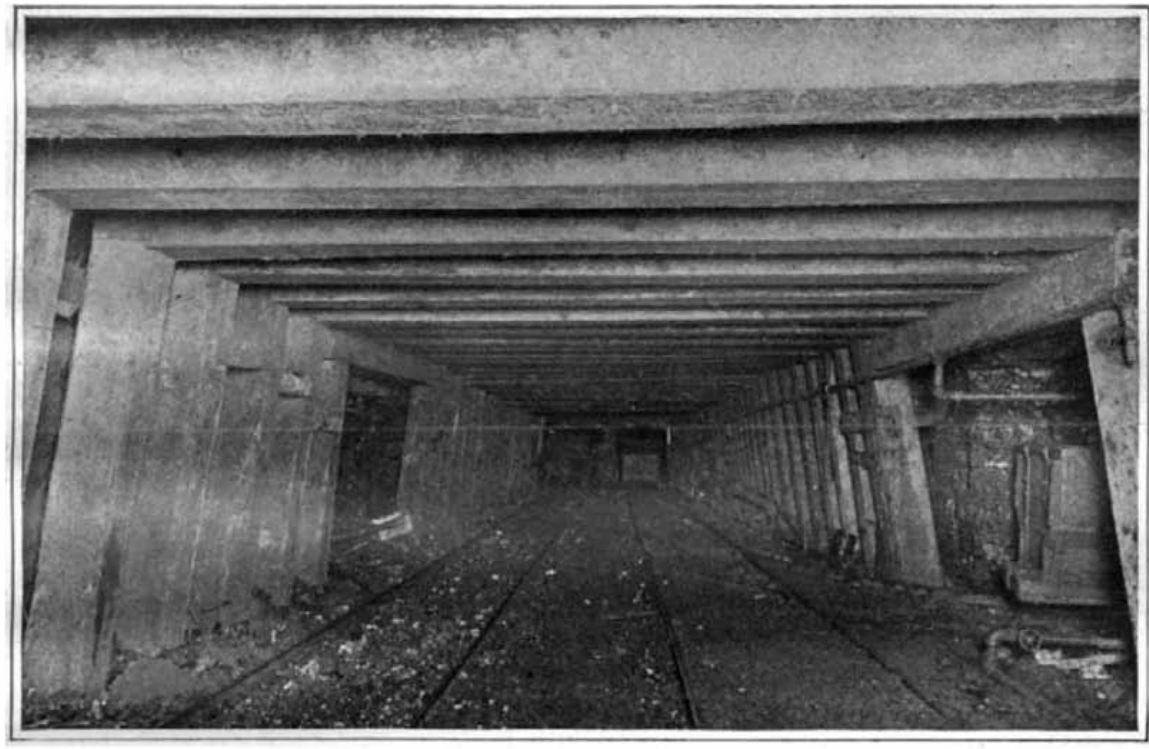

Good haulage minimizing production of coal dust

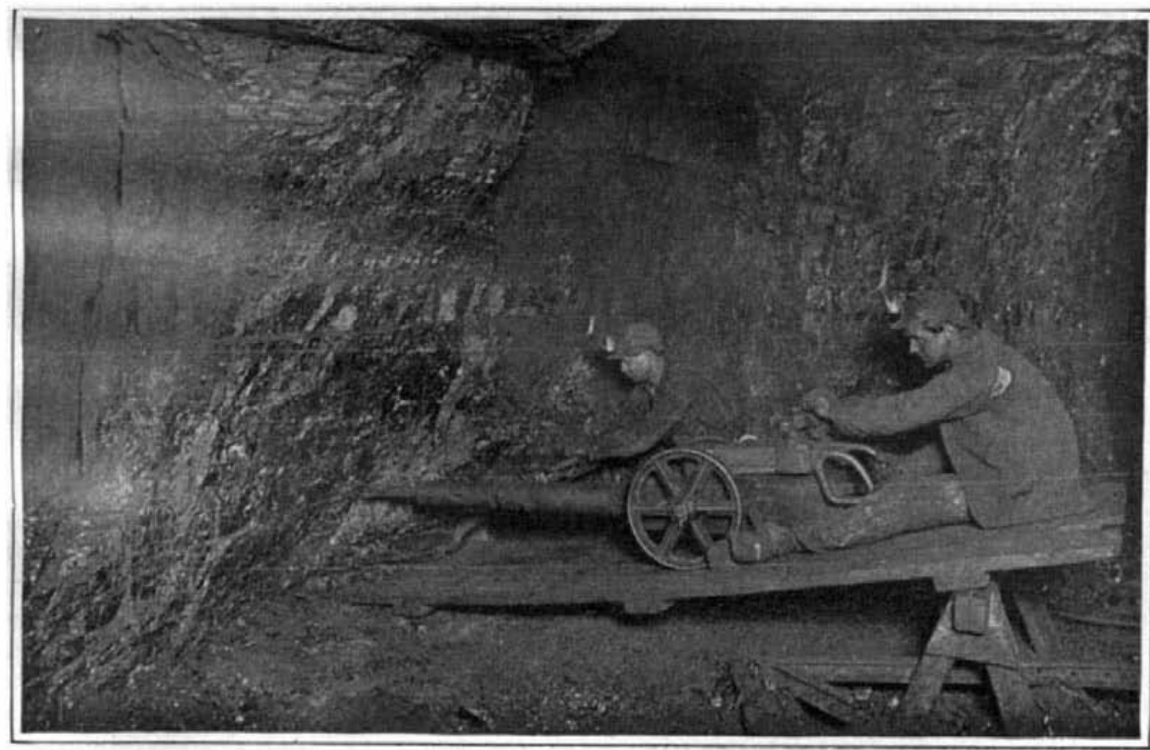

Undercutting coal with compressed air drill. THE USE AND WASTE OF OUR COAL SUPPLY

\section{Losses in the Use of Coal.}

Great as are the losses of coal in mining, they are proportionately less than in its burning in the furnace of the country. The experienced manfacturer who, as a large consumer o coal, habitually watches the double en ries on the pages of his ledger for profits and losses, does not hesitate to express his surprise and disapproval when he hears the story of rrining losses, approximately 250,000 , 000 tons of coal in a single year; but in doing this he often loses sight of the no less serious fact-that of the coal used in his own furnaces, less than 10 per cent of its heat units are converted int mechanical work in his factories; or the larger fact, that of the $300,000,000$ tons of coal probably used in the power plants of the coun try (including locomotives), 270,000 iost in the several transformations of energy; and not more than 10 per cent of the heat units, or the equivalen of only $30,000,000$ tons of this coal, was transformed into the mechanical work of the nation.

The situation seems clearer if these losses are subdivided or classified. This cannot be done accurately in $a$ general statement, because of the variations in the different furnaces, boilers and engines. But taking a common type of smaller power plant, ihe disposition or consumption of British thermal units in the burning of the ordinary bituminous coal (contain ing 13,500 B. T. U.) has been given a follows:

B. T. U. cent. $\begin{array}{lll} & 135 & 1.00\end{array}$ $\begin{array}{lll} & & \\ & & \end{array}$ Loss in radiation from boilers

Carried off in auxiliary exhaust Loss in radiation and leakage, main pipes. Loss in radiation from 'small pipes

Less in radiation from engine .............. $\begin{array}{lll} & 280 & 2.07\end{array}$ Rejected to condenser.. 7,737 57.31 Coisverted to power or

mechanical work.... $1,275 \quad 9.43$ $\overline{13,500} \overline{100.00}$

The government of the United States is probably the world's largest owner is probably the world's largest owner
of coal lands; it also operates a large of coal lands; it also operates a large number and variety of heating and power plants located in widely septhe Panama railroad, lines of transport steamers, and its naval vessels. Furthermore, the fuel problem enters so largely into the manufacturing, transportation and interstate commerce of the whole cointry that they nary be reasonably classed as national problems

In recognition of these facts, Congress several years ago authorized an investigation of fuel probjems, first under the Geological Survey, and subsequently under the Bureau of Mines. Lrider the latter bureau this work is now being reorganized, and co-operating with other existing agencies, the engineers and chemists of the Bureau f Mines, working at its Pittsburg laboratories, are endeavoring to locate and reduce or eliminate as far as may be possible the sources of loss or waste rot only in the mining, but also in the use of our fuel resources.

(Continued (n page 150.)

* This does not include a loss which in extreme cass may reach $2 \pi$ per cent of the coal, where finely divided non-coking coal passes through the grate hars in an un-
burned condition, along with the ashes. 
The Use and Waste of Our Coal Supply

(Continued from page 1:.

These problems are intricate, and their satisfactory solution doubtless remote, but they are of such importance as to be worthy of the best efforts of the Government and of its private institution and individual citizens.

In engineering and architecture we hide our ignorance as to the strength and other properties of structural mate-
rials behind the well-sounding phrase "factors of safety." In these importan "factors of safety. In these importan and intricate fuel problems we hide our ignorance and rest our laurels concern forting expression, "transformation of energy." What American industry need: is technical information, accurate fundamental data, such as comes from varied, extended, continuous, well directed, and cientific research.

Each recent year has witnessed some advance in the line of greater fuel effciency; and while each advance has been mall, the aggregate has during the past decade raised the percentage of heat units converted into mechanical work from five or six to nine or ten, and slightly more gas engine, the steam turbine, and the improved recine,

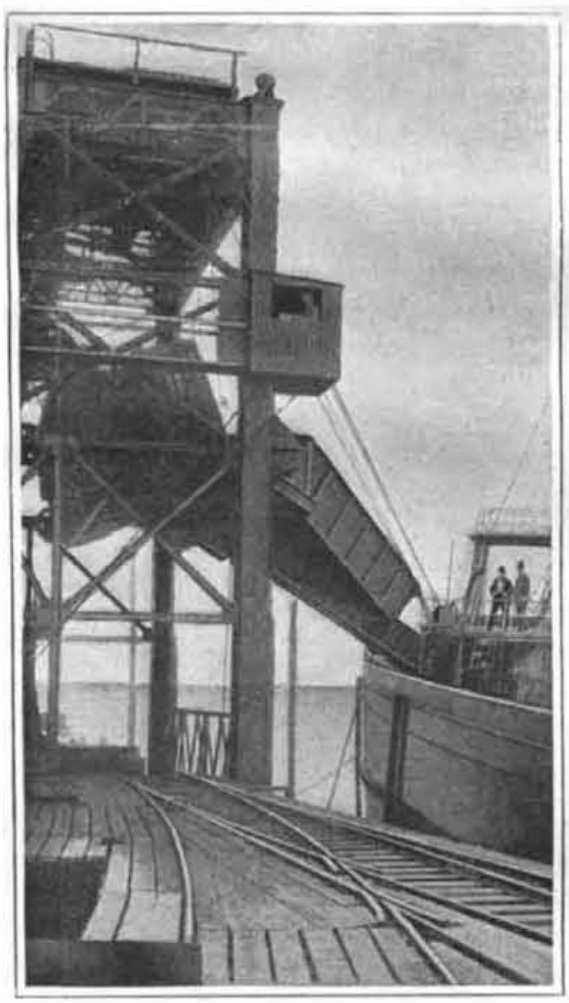

Coal car is picked up bodily, turned over and discharges to chute.

development and introduction of the several types of automatic stokers; these la ter contributing to efficiency and at the from modern

These automatic stokers and special grates have further contributed to the conservation of resources by making possible the more efficient burning of fine or slack coal, which formerly was relegated to culm piles as waste, and as such to be burned in the open air. Briquetting to be burned in the open air. Briquetting is making another contribution along the tion of practical conservation, cleanliness, tion of practical conservation, cleanliness, and hygiene-and one that should be pushed more rapidly - is the location of
the great power plants at the mines, and the great power plants at the mines, and the burning there, either in gas producers or specially constructed furnaces, of the low grades of coal now thrown away be cause they will not bear transportation; and the electric transmission of the power so developed to adjacent cities, towns and isolated plants.

I look forward to a time-and it cannot, I believe, be far distant-when and brought into our factories and homes will not only give us light and power, but will also cook our food and warm our houses.

Two other marked advances in the tion because of both their extent and their far-reaching importance; one is the their far-reaching importance; one is the by-product coke for the latest steel plants by-product coke for the latest steel plants
of the United States Steel Corporation, petition with operators in other States. products as creosote for the preservation largely used in the fertilizing of crops. The other is the use in large gas engines were entirely, and in many places are till largely wasted. The losses in these two fields, added to the shameful waste of natural gases, still aggregate yeary
from $\$ 50,000,000$ to $\$ 100,000,000$; but imrovements are under way in all these How These Mining Losses May Be Reduced.

No one questions the fact that these osses are real; nor are there any serious ion that these losses as to the propos Just how this best can be done is another matter, and one about which a difference opinion may naturally arise. The sitfor the statesman, the engineer and the conomist, the consumer and the producer. It involves the very essence, the movement for the conservation of $r$ The case may be stated as follors: We have but the one supply of coal, and this supply is essential to both the future and the present welfare of the
nation. At the present increasing rat

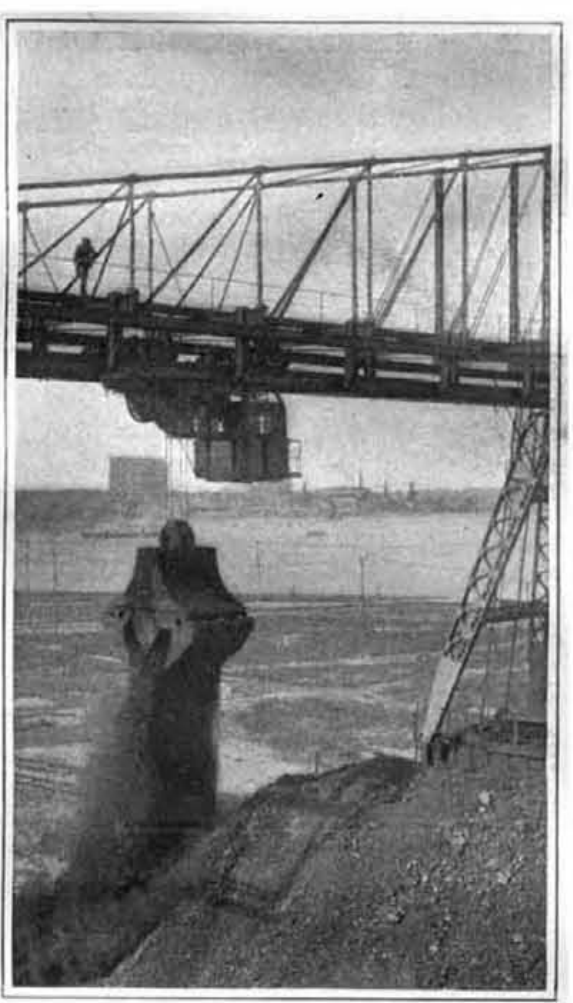

Much coal is lost as dust during handling.

of use and waste of this supply, it will is yet in its youth. By mine the nation this coal more efficiently, the life of tha supply may be extended indefinitely, an the nation thus properly safeguarded. The coal operator does not practise wastemethods by preference. $\mathrm{He}$ is, however, operating under a system that en these wasteful practices; and for which stem the public itself is largely responA.

A Federal statute makes it impossible for the coal producers to co-operate or
combine with a view to fixing a common or non-competitive price for coal at the mine. The demand for coal during the in excess of that during the warmer months, and the entire lack of storage cold weather demand a mining capacity much in excess of that necessary for the summer needs. Under such a system struggle for business, and a reduction o prices so low that they often fail to low that safe and clean mining is discouraged and even rendered impossible. mining laws for the protection of life and property, nor will any State enact, nforce, if it enacts, drastic legislativa been continuous playing for years to enact and enforce the Federal and State legislation necessary for the accomplis:-
ment of these ends. We should render possible the business-like reorganization of this great basic industry. We should see to it that this underlying economic basis is sound, whether judged from the
standpoint of the individual or the naion-from the standpoint of the present

\section{The Vibrations of Metals}

$\mathrm{T}$ has been contended that solid metals ions to which their structure the vibraIn explaining this phenomenon, experiments were made in England to show that a beautiful wave structure can be me vibration surface of mercury by even the surface of solid lead which has possesses a structure resembling that of a vibrating surface of mercury. Mild
steel was defined as a "solid solution" of iron and carbon, free from cinders. Metallurgists have doubled the strength one of the most dangerous of all explo sives. When dry, the slightest touch will often cause it to explode with great

There appears to be a certain rate of vibration which this compound cannot resist. In experiments to determine the damp iodide of nitrogen was rubbed on the strings of a bass viol. It is known that the strings of such an instrument will vibrate when those of a similar instrument, having an equal tension, are played upon.

had become thorough'ly dry upon the strings, another bass viol was brought a certain note the iodide of nitrogen At the prepared instrument exploded. It was found that the explosion occurred only when a rate of vibration of
60 per second was communicated to th prepared strings. Vibration of the $G$ string caused an explosion, while that of the E string had no effect. The question is often asked, What
force least expected does the greatest damage to buildings? One architect's answer to this question may be a sur-
prise to those who do not understand that makes it powerful.

"I venture to say," remarked this architect, "that you would never suspect that violin-playing would injure the walls of a building. Yet it certainly does.
There have been instances when the There have been instances when the
walls of stone and brick structures have been seriously damaged by the vibrations of a violin. These cases are, of course "The but the facts are established. serious in their unseen, unbounded orce, and when they come with regularity, they exercise an influence upon ollows, of course, that there must have canse the loosening of masonry or to
LEGAL NOTICES

\section{PATENTS}

If you have an invention which you wish to
patent you can write fully and freely to Munn patent you can write fully and freely to Munn
$\&$ Co. for advice in regard to the best way of obtaining protection. Please send sketches or a
model of your invention and a description of the device, explaining its operation.

All communications are strictly confidential. Our vast practice, extending over a period of
more than sixty years, enables us in many cases to advise in regard to patentability without any
expense to the client. Our Hand Book on Patents is sent free on request. This explains our
methods, terms, etc. in regard to PATENTS,
TRADE MARKS, FOREIGN PATENTS, etc. All patents secured through us are described
without cost to the patentee in the SCIENTIFIC
AMERICAN. MUNN \& COMPANY 361 BROADWAY, NEW YORK Branch Office, 625 F Street, Washington, D. C. been subjected to similar vibrations steel as it was known in early days. that it is the regularity of vibration make i
A T EN TS SECURED OR FEE Free report asto Patentability. Illustrated Guide
Brok. and What To Invent witb List of Inventions Wanted and Prizes offered for inventions
tee. VICTOR J. HV ANS \& CO.. Wasbington. D.C.

Classified Advertisements

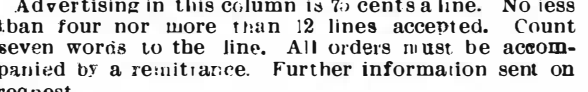
HELP WANTED.

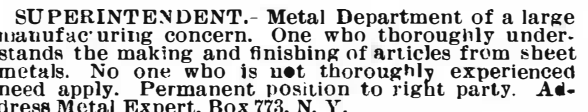
PATENTS FOR SALE

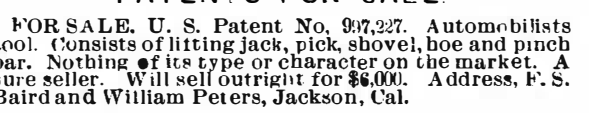

WANTED.

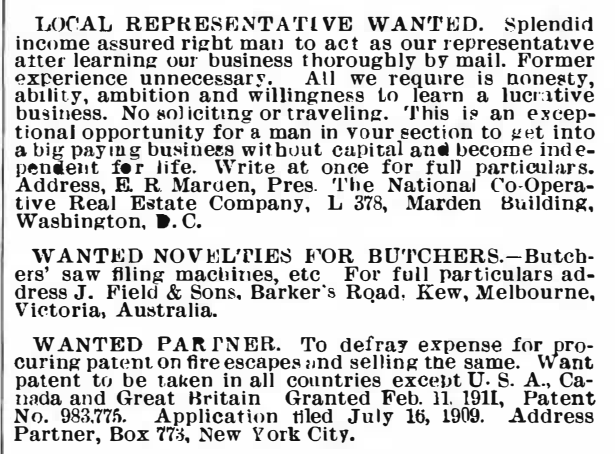

MISCELLANEOUS

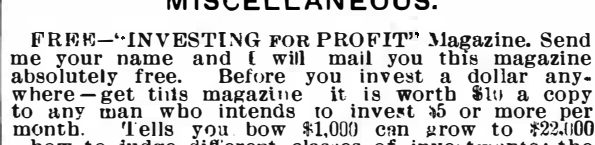

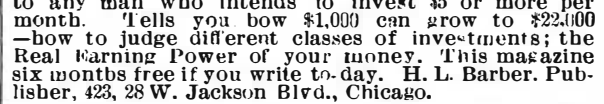
MAKE BIG MONEY operating a Daydak post Card
Macbine. Pboto postal car os made and delivered on
the spot in ten minutes in the cpen street. No dark
room necessary it does not require an experienced

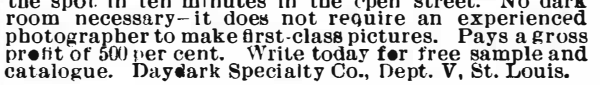

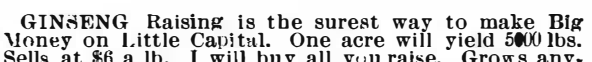

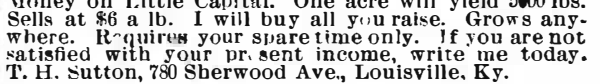

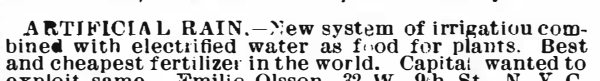

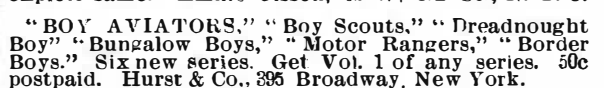

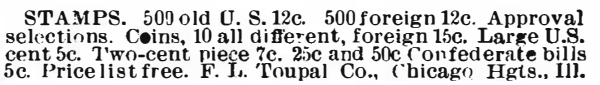

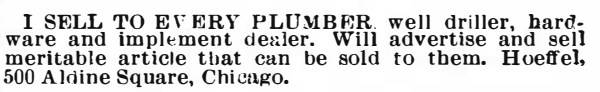

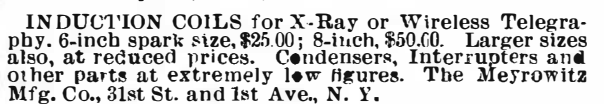

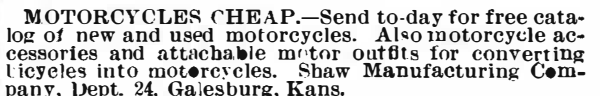

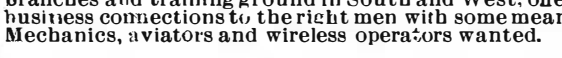

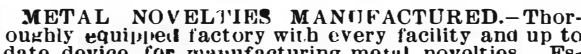

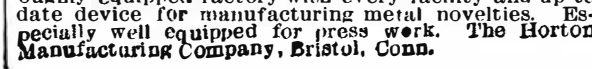

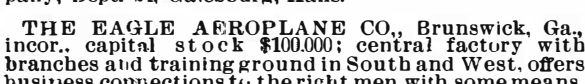




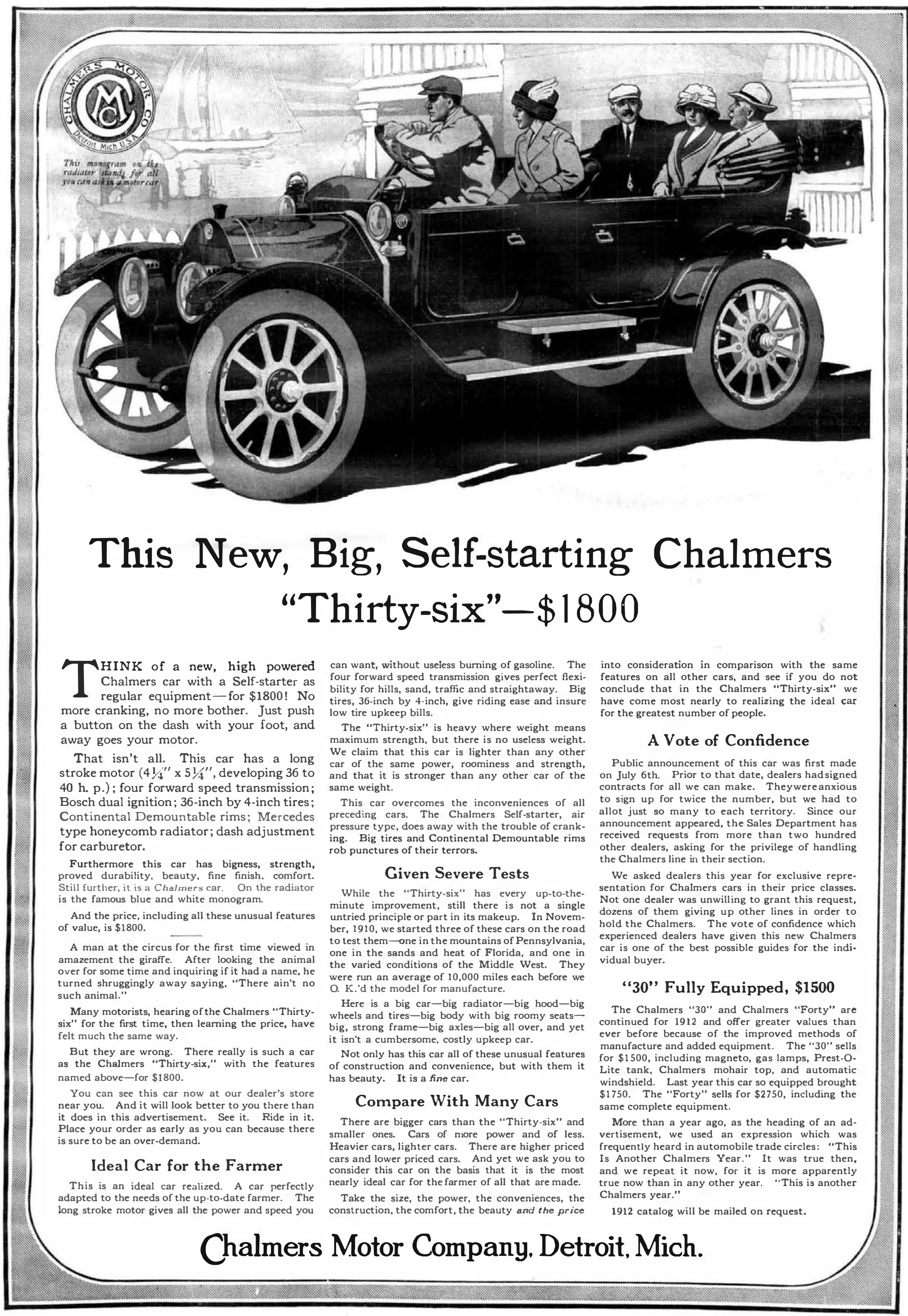

